\section{EMBRYAIDDLE Aeronautical University}

SCHOLARLY COMMONS

\section{International Journal of Aviation,} Aeronautics, and Aerospace

\title{
Aviation Managers' Perspective on the Importance of Education
}

\author{
Jason M. Newcomer \\ Embry-Riddle Aeronautical University - Worldwide, jason.newcomer@erau.edu \\ James W. Marion Jr \\ Embry-Riddle Aeronautical University - Worldwide, marionj@erau.edu \\ Matthew P. Earnhardt \\ Embry-Riddle Aeronautical University - Worldwide, earnharm@erau.edu
}

Follow this and additional works at: https://commons.erau.edu/ijaaa

Part of the Business Administration, Management, and Operations Commons, Higher Education Commons, and the Training and Development Commons

\section{Scholarly Commons Citation}

Newcomer, J. M., Marion, J. W., \& Earnhardt, M. P. (2014). Aviation Managers' Perspective on the Importance of Education. International Journal of Aviation, Aeronautics, and Aerospace, 1(2). https://doi.org/10.15394/ijaaa.2014.1014

This Article is brought to you for free and open access by the Journals at Scholarly Commons. It has been accepted for inclusion in International Journal of Aviation, Aeronautics, and Aerospace by an authorized administrator of Scholarly Commons. For more information, please contact commons@erau.edu. 


\section{Aviation Managers' Perspective on the Importance of Education}

\section{Cover Page Footnote}

We would like to acknowledge all of the aviation industry managers that contributed to the study. Your contribution is valuable and greatly appreciated. 
Beginning with the first flight of the Wright Brothers in 1903, aviation has engrained itself as not only a mode of transportation and as a means to defend the nation, but as part of the American culture as well (Newton, 2004; Wicks, 2003). From its humble beginnings, the aviation industry has rapidly expanded providing tremendous employment opportunities, numerous companies dedicated to aviation, and billions of dollars in annual revenue. Coinciding with the growth of the aviation industry has been the need for increased aviation education and certification. The potential return on investment for a college education has been studied by scholars for decades. Carkeet (1980) conducted the first study on aviation leader education. Since then, there has been little aviation-specific research examining the relationship between aviation manager education and workforce demographic data, such as salary, management level, type of industry, and type of degree (Appelbaum $\&$ Fewster, 2002). Although Jensen (2010) demonstrated that there is a positive return on investment for the majority of individuals who received a college education, there are no empirical studies to demonstrate the applicability of those studies specifically to the aviation industry. Therefore, the current study seeks to fill the literature gap through an investigation of aviation managers' perceptions of post-secondary education.

\section{Problem Statement}

The U.S. Department of Labor reported that working adults with at least a four-year college degree earned an annual average salary of $\$ 63,400$ compared to the $\$ 24,300$ salary of high school graduates with no college (Bureau of Labor Statistics, 2014). Furthermore, a number of business studies demonstrated a positive correlation between higher education and sustainability, personal growth, and national prosperity (Haase, 2009; Paraschivescu \& Radu, 2011; Robinson, 2013; Walsemann, Bell, \& Hummer, 2012). Carkeet (1980) conducted a study that specifically focused on education and leaders in the aviation industry, and what faculty qualifications were necessary to prepare students for aviation leadership careers. Since this study, corporate America and the aviation professions have changed due to increased air travel, outsourcing functions, aviation research, federal regulation, and the changed U.S. economy (Katkin, et al., 2013; Mootien, Warren, Morris, \& Enoch, 2013; Quinlan, Hampson, \& Gregson, 2013; Rango \& Laliberte, 2010). The specific problem is the lack of current demographic and other qualifying data on aviation managers, as well as any associated analysis or significance testing of the aforementioned data. Given the aforementioned, little empirical evidence exists regarding the requisite education needed to join the ranks of management in aviation. 


\section{Purpose Statement}

The purpose of this quantitative, non-experimental study is to describe the impact of college education on managers in the U.S. aviation industry so that aviation educators can better prepare their students for professional success. Additionally, this study will address a three and half decade gap in the literature regarding aviation managers' perceptions of post-secondary education.

\section{Significance of the Study}

Given the aforementioned benefits of education, coupled with the lack of current research concerning aviation, the results of this study might provide any number of benefits to both the education and business community. For researchers, the results of the study can serve as a foundation for justifying targeted empirical research in the field. The lack of empirical evidence on aviation education could be that aviation has been typically considered a closed group to researchers (Eaton, 2001). This study is the first of its kind to gain access to this population and provide some insights for future research. For the aviation industry, the resultant descriptive data and analysis of manager responses can provide intra-disciplinary transformation insight for organization improvement. Academic institutions might also use the resultant data to more effectively align their academic, professional development, and research programs to either more closely tailor to the current demographics or to produce graduates capable of filling existing talent gaps as reflected by the aggregate population of aviation managers sampled. Furthermore, those interested in aviation as a career choice may use the results of this study to guide their decision on college majors.

\section{Assumptions, Limitations, and Delimitations}

\section{Assumptions}

The following assumptions underlay the research design:

1. Due to the anonymity afforded by the Aviation Management Education Survey (AMES), participants provided honest feedback concerning the questions therein. This assumption is based on the protection afforded by the protection provided by the anonymous survey, informed consent that describes the importance of the study to the aviation community, and ability for a participant to withdraw from the study at any time. 
2. The aggregate opinions of the participants are representative of the larger aviation management community. This assumption is based on the results of the sample size calculations further discussed in Section 2 of the study.

3. The results of the study are generalizable and can be replicated by future researchers.

\section{Limitations}

1. Due to our limited access to aviation managers, we limited our study to an audience of over 300,000 members of various aviation professional social media groups. The link to the data collection device was posted within the aforementioned groups to attract participants.

2. As an exploratory study, and the first of its kind since Carteek (1980), the study fills a gap that serves as the foundation for future areas of exploration. Given the foregoing, the scope is both deliberate and broad, exploring the aviation industry as a whole and not specifically addressing any particular field. In some instances, the at large findings might not apply to some of the specific sub-elements within the field of study. In such instances, figures depicting the outliers and a recommendations section identify areas where more specified research is warranted.

\section{Delimitations}

The number and scope of our selected research questions are the main delimitations within the study. Due to the vast amount of data collected, we selected the questions that we thought most relevant to the problem statement with the understanding that there are exponentially more and varied questions that could be investigated as part of a larger study or smaller studies subsequent to this one.

\section{Conceptual Framework}

Through this study, the researchers aimed to reinvigorate the questions surrounding the gap on aviation management education that researchers have not addressed since Carteek's (1980) seminal work. As such, it was necessary for us to follow an approach that would contribute by forming a foundation for future, more specific, areas of study to be built upon. The aforementioned goal supported the need for us to employ the National Aeronautics and Space Administration's (NASA) (NASA, 2010) systems engineering work breakdown structure (WBS) as a framework for our approach. The WBS framework is hierarchical in nature where 
an engineer starts at the top, with the broad topic and then determines the rest of the more detailed hierarchy of subjects that support the main topic (NASA, 2010). Figure 1 contains a sample of what the research initiatives might look like as the knowledge gap is filled by supplemental studies using the WBS approach.

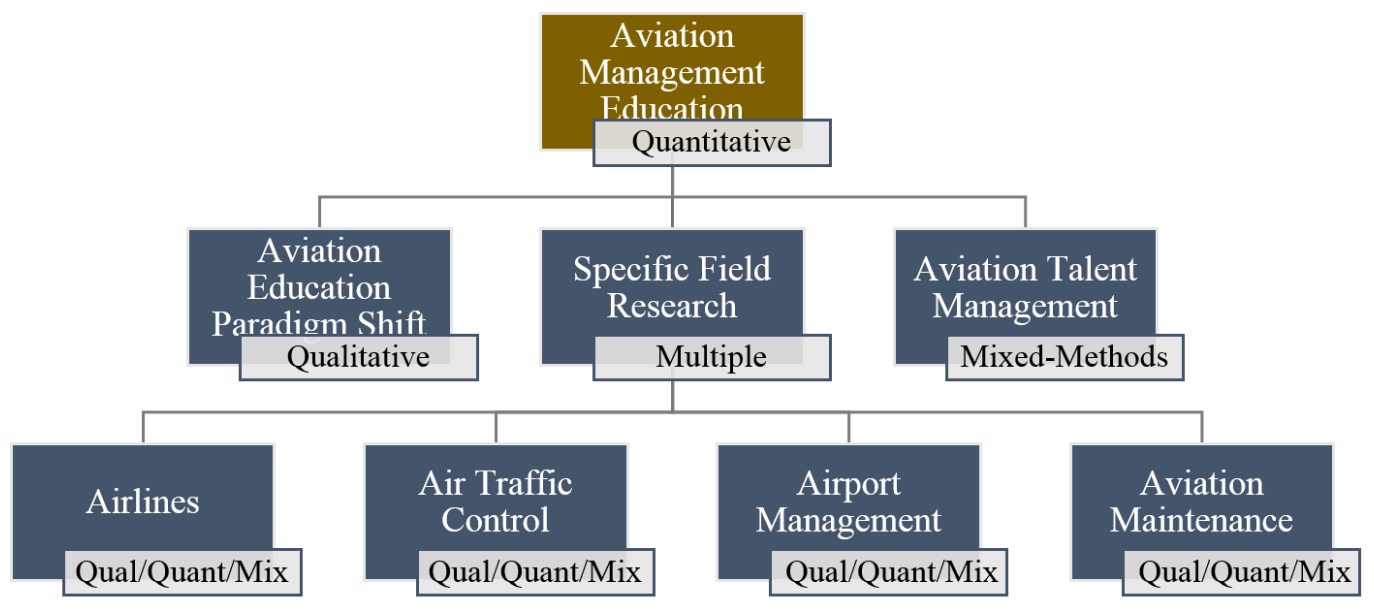

Previous

Current

Literature Gap

Figure 1. A hypothetical application of the systems engineering WBS approach to filling the gap that exists regarding aviation management education. As demonstrated above, the results of this study can highlight more specific gaps in various areas of aviation management education that can be explored using various methodologies to provide quantifiable findings supported by qualitative depth of scholarship.

\section{Review of Literature}

The aviation industry continues to change in social, political, and economic areas (Katkin, et al., 2013; Mootien, Warren, Morris, \& Enoch, 2013; Quinlan, Hampson, \& Gregson, 2013; Rango \& Laliberte, 2010). As the aviation industry evolves, education needs continue to change to meet the demands of an ever changing industry. Though several business studies have noted a positive correlation between higher education and sustainability, personal growth, and national prosperity (Haase, 2009; Paraschivescu \& Radu, 2011; Robinson, 2013; Walsemann, Bell, \& Hummer, 2012), there is a dearth of research that has explored education in aviation among managers. Therefore, it was critical to set the stage for the current study through a literature review exploring the history of the aviation industry, as well as selected research related to aviation managers, management higher education, and aviation training and education. 


\section{Aviation Industry History}

When the Wrights launched their flyer in 1903, they forever changed the landscape of America and the world (Noor, Venneri \& Creedon, 2003). As noted by George (2012), "It is safe to say that the aviation industry did not have a large place in the U.S. economy before the Wright Brothers flew at Kitty Hawk in 1903" (p. 63). Since the Wright brothers foundational flight, inventors quickly challenged the Wright brothers dominance of controlled powered flight, leading to growth of the aviation industry during its infancy (Sampson, Jr. \& St. James, II., 2012).

The early U.S. aviation industry evolved from U.S. postal service and military use, largely due to World War I and the passing of the Airmail Act of 1925. World War I (and later, WWII), were critical to the early U.S. aviation infrastructure and the Airmail Act of 1925 authorized the government to award contracts to air carriers for delivering mail. Once the U.S. Congress passed the Air Commerce Act of 1926, which promoted further the development of U.S. aviation legal and physical infrastructure, a series of acts followed that commercialized quickly the aviation industry (Sampson, Jr. \& St. James, II., 2012). As the interest in airplane travel grew in the 1940's and 1950's, the market was expanding but still small enough where data reporting from the government was limited. "The Bureau of Economic Analysis (BEA) accounts of economic output began breaking out data by industry in 1947. In 1947, aerospace manufacturing was lumped into the aggregate manufacturing accounts and air transportation did not even exist as a subaccount" (George, 2012, p. 63). As George (2012) noted, air transportation finally was given its own BEA category in 1977, with the aviation industry accounting for $1.5 \%$ of the economy.

By 2010, those numbers would change significantly with $0.8 \%$ of all U.S. employment having been accounted from the aerospace and aviation industries (George, 2012). Sampson, Jr. and St. James, II (2012) emphasized the strength of the U.S. aviation industry at the time by highlighting the massive amount of exportable aerospace products, increased demand of U.S. aircraft creating an extensive manufacturing backlog, and transfer of aviation mentorship to both internal and external users.

\section{Aviation Managers}

As noted by Appelbaum and Fewster (2002), there is scant attention given in the literature toward airline management, leaving a major gap that needs to be filled. Though there are several reasons that could be given for this, Eaton (2001) noted that airline managers appear to be more closed to academic research than 
other industries. Despite the lack of research compared with other industries, several studies have investigated aviation managers allowing some important conclusions to be drawn.

Romano (2003) asserted that most companies within the aerospace industry operate in a command and control system; largely due to the significant number of military veterans within the industry that are accustomed to such functionality. Romano (2003) further noted that management in the aerospace industry is based on transactions and that aviation managers expect a return on investment, in the form of productivity and its resultant added value, for wages paid. The aforementioned work culture plays a significant role in manager and subordinate relationships. Yi-Hsin (2012) studied safety behavior among pilots and found that managers played a significant role in establishing organizational commitment among their employees and in using a safety mission statement to change safety behavior and increase the benefits of brokering knowledge. In other words, aviation industry managers play a significant role in establishing organizational culture. The foregoing was substantiated by McCain (2010) who recommended that, due to the criticality of their role, aerospace managers communicate better the mission to subordinates.

Tjorhom (2010), using a case study, investigated risk governance within aviation by interviewing several actors, such as managers, government regulators, and advisors, within the Norwegian civil aviation transportation system. One important note from Tjorhom's (2010) study is the commitment of aviation managers to both lifelong learning and flexibility. Swartz (2008) investigated stability within project outcomes by utilizing a sample of aviation systems design managers. Swartz (2008) found that stability and earned value among aviation managers had high importance; however, perceptions varied based on the size, scope and stage of completion of the program and project. Experience and certification level also had a significant role on perceptions of earned value and stability.

\section{Management Higher Education}

Research on the importance of higher education in the management ranks and employees are numerous and far-reaching in a variety of industries. For example, screen producers have been found to not value tertiary education as a benefit to their careers (Cameron, Verhoeven, \& Court, 2010) while McKee and Silver (2012) found that producer perceptions of a degree related to their specific industry would be of value. In a study of German nurses investigating the role of an academic education on self-esteem, it was noted that nurses with academic 
degrees had a significant higher level of self-esteem than counterparts without formal education (Van Eckert, Gaidys \& Martin, 2012).

In a study by van Praag, van Witteloostuijn and van der Sluis (2013) found that entrepreneurs have higher levels of returns from their formal education than employees. Van Praag et al. (2013) hypothesize that this could be due to fewer organizational constraints and more personal control over their human capital than employees. In a study by Chen and Doherty (2013), an Executive Master of Business Administration program was seen as critical to developing the skills of managers in China. Zinko, Gentry, Hall, and Grant (2012) investigated the impact of education on reputations after attending a leadership development program. Results indicated that managers were able to improve their reputation after completion of the formal program. Bastos and Monteiro (2011) found that managers wage policies are impacted by employee's education level among other factors. In a study of 99 individuals partaking in executive education programs, $80 \%$ or above found that certification and recognition were important to participants; indicating the importance of credentials for executives undergoing a course of study (Daniels, 2011).

In addition to the aforementioned studies, it was interesting to note that research does not just focus on managers with degrees. Research on first-tier and middle managers that do not possess a college education found that when they return to school they make successful students because of commitment to study and skills in the workplace (Pollitt, 2010). Pollitt (2010) further noted that these managers translate their studies to the world of work.

\section{Aviation Training and Education}

As noted by Wofford, Ellinger and Watkins (2013) learning is life-wide and takes place not only in former education settings but also at home and work. Wofford et al. (2013) found that informal learning is important to the aviation industry, which is in agreement with previous research. Pourdehnad and Smith (2012) found that the commercial aviation industry has created a learning and adaptation support system that has increased air safety. Tomczyk (2010) developed a flying laboratory for aeronautics students' education and found that simulations were useful in aeronautic student education. Minkes and Small (2010) studied four learning organizations and found that the aviation safety organization considered itself a learning organization and consistently scanned and implemented research regarding technology training and aircraft specific safety seminars. LaPoint (2012) found a correlation between crew resource management intervention and postintervention changes following an aviation-based training program. Finally, 
Koskela and Palukka (2011) found that in air traffic control training that two training techniques, simulator training and on-the-job training, can be better reconciled.

\section{Research Questions}

a) Do aviation managers have an opinion regarding the importance of education for attaining their current positions?

b) Do aviation managers have an opinion regarding the need for newly hired direct reports to have a degree?

c) Is there any association between degree level attained and level of management?

d) Is there any association between degree importance perception and (a) management level, (b) company type, (c) salary range, (d) years in position, (e) size of company, (f) level of education, (g) industry category, and $(\mathrm{h})$ degree field of study?

\section{Hypotheses}

a) Level of education and current employment:

a. $\mathrm{H}_{0}$ : The responses of aviation managers regarding the importance of education to their current employment are equally distributed across all response choices.

b. $\mathrm{H}_{\mathrm{a}}$ : The responses of aviation managers regarding the importance of education to their current employment are not equally distributed across all response choices.

b) The education of direct reports:

a. $\mathrm{H}_{0}$ : The responses of aviation managers regarding the need for newly hired direct reports to have a degree are equally distributed across all response choices.

b. $\mathrm{H}_{\mathrm{a}}$ : The responses of aviation managers regarding the need for newly hired direct reports to have a degree are not equally distributed across all response choices.

c) Degree and level of management:

a. $\mathrm{H}_{0}$ : There is no association between the degree level attained, and aviation managers' level of education.

b. $\mathrm{H}_{\mathrm{a}}$ : There is an association between the degree level attained, and aviation managers' level of education. 
d) Association between degree importance perception and (a) management level, (b) company type, (c) salary range, (d) years in position, (e) size of company, (f) level of education, and (h) degree field of study:

a. $\mathrm{H}_{0}$ : There is no association between degree importance perception and management level.

$\mathrm{H}_{\mathrm{a}}$ : There is an association between degree importance perception and management level

b. $\mathrm{H}_{0}$ : There is no association between degree importance perception and company type.

$\mathrm{H}_{\mathrm{a}}$ : There is an association between degree importance perception and company type.

c. $\mathrm{H}_{0}$ : There is no association between degree importance perception and salary range.

$\mathrm{H}_{\mathrm{a}}$ : There is an association between degree importance perception and salary range.

d. $\mathrm{H}_{0}$ : There is no association between degree importance perception and years in position.

$\mathrm{H}_{\mathrm{a}}$ : There is an association between degree importance perception and years in position

e. $\mathrm{H}_{0}$ : There is no association between degree importance perception and size of company.

$\mathrm{H}_{\mathrm{a}}$ : There is an association between degree importance perception and size of company.

f. $\mathrm{H}_{0}$ : There is no association between degree importance perception and level of education.

$\mathrm{H}_{\mathrm{a}}$ : There is an association between degree importance perception and level of education.

g. $\mathrm{H}_{0}$ : There is no association between degree importance perception and degree field of study.

Ha: There is an association between degree importance perception and degree field of study.

\section{Methodology}

Quantitative research is most appropriate when the nature of the study is to examine the relationship among variables particularly those collected via an instrument that can be translated into numbers for statistical analysis (Creswell, 2009). Multiple studies within the literature review, covering both aviation and education, employed effectively the quantitative methodology (Lin, 2012; Walsemann, Bell, \& Hummer, 2012). Because the purpose of the study is to collect demographic and perception data for statistical analysis, the quantitative method 
best addressed the research questions. The data collected by the survey were composed of non-parametric data; therefore, the appropriate means for testing the association between variables was to employ the chi-square test.

\section{Population and Sampling}

We selected managers in the aviation industry as the research population for this study because they are best postured to provide information to fill the knowledge gap on aviation manager education. For a participant to qualify as a manager, their position in the organization had to meet the criteria for top, middle, or lower level management:

- Top level managers serve in the roles of executives that oversee company functions at the strategic level. Examples of top level managers are C-level managers and presidents.

- Middle level mangers serve in roles that oversee organizational and directional functions according to policy and plans developed by top level managers. Examples of middle level managers are branch, department, and division managers or chiefs.

- Lower level managers are responsible for personnel supervision and/or significant resource management. Examples of lower level managers are supervisors, section officers, superintendents, and resource managers.

For the purpose of this study, managers in the aviation industry belonged to the following type of organizations: (a) airlines, (b) airports, (c) air navigation, (d) aircraft maintenance, (e) aviation education, (f) military (direct relation to aircraft operations), (g) aircraft and aircraft systems manufacturing or design, (h) aviation logistics, (i) federal aviation, (j) aviation support services, (k) and contractors that perform management functions in the aforementioned organizations.

Our sampling technique involved a combination of random and convenience sampling. We provided the hyperlink for our data collection device to professional contacts so that they might distribute it within their organizations. Simultaneously, we posted the data collection link in multiple aviation and aerospace groups and forums on the world-wide web and several social media websites to maximize the number of respondents. The results of the sampling are described in the following section. 


\section{Data Collection and Analysis}

\section{Pilot Study}

Yin (2009) and Schmader (2011) highlighted the importance of conducting pilot studies prior to employing a research instrument in order to improve the data collection instrument's questions and research validity. Given the foregoing, we distributed the AMES-1 to 35 professors in an aviation university department to solicit feedback on question transparency, validity, and simplicity. We received nine responses containing suggestions for question improvement, to include: allowing multiple selections for some responses, the addition of the "other" category for miscellaneous items we did not consider during development, dictation suggestions to improve clarity, and additional degree choices for the degree subject matrix. Once all suggested modifications were vetted and implemented, we proceeded to collect data.

\section{Collection and Treatment of the Data}

The data collection period was cross-sectional, covering a period of three weeks. At the completion of the three week data collection period, the survey data were imported from the SurveyMonkey database into an Excel spreadsheet. The raw data were filtered to remove non-industry executives and blank responses. Out of 166 aggregate responses, 49 were disqualified for not being aviation managers and an additional 14 were disqualified due to incomplete data. The data was further organized so that each hypothesis could be tested using chi-square analysis.

Following the data collection, we employed a goodness of fit chi-square analysis to the data to better understand the effects of college education on managers in the U.S. aviation industry. The following section contains the results of the statistical analysis as well as our interpretation of the results. Throughout the tables and charts to follow, we used the abbreviations in Table 1.

Table 1

Legend of Abbreviations

\begin{tabular}{lc}
\hline \multicolumn{1}{c}{ Answer Option } & Abbreviation \\
\hline Strongly Disagree & SD \\
Disagree & D \\
Neither agree nor disagree & NANDA \\
Agree & AG \\
Strongly agree & SA \\
\hline
\end{tabular}




\section{Results}

\section{Hypothesis A: Level of Education and Current Employment}

Hypothesis:

a. $\mathrm{H}_{0}$ : The responses of aviation managers regarding the importance of education to their current employment are equally distributed across all response choices.

b. $\mathrm{H}_{\mathrm{a}}$ : The responses of aviation managers regarding the importance of education to their current employment are not equally distributed across all response choices.

A chi-square goodness of fit test was conducted to assess whether aviation managers do not consider level of education essential for attaining their current positions. The results were significant, $\chi^{2}(1, N=103)=12.19, p<.001$. Although the results differ significantly from the expected value, it is important to ask, "In what way are they different overall? Of the 103 total responses, 46 responded with "Agree or Strongly Agree", while 57 responded with either "Neither agree nor disagree, disagree, or strongly disagree". The evidence therefore suggests that aviation managers do not consider level of education essential for attaining their current positions. Results are presented in Table 2.

Table 2

Chi-square Calculations for Hypothesis A

\begin{tabular}{lcccc}
\cline { 1 - 3 } \multicolumn{1}{c}{ Answer Options } & Response $\%$ & Observed N & Expected N & $\begin{array}{c}\text { Chi } \\
\text { Sq }\end{array}$ \\
\hline Strongly disagree & $7.80 \%$ & 8 & 20.6 & 7.71 \\
Disagree & $24.30 \%$ & 25 & 20.6 & 0.94 \\
Neither agree nor disagree & $23.30 \%$ & 24 & 20.6 & 0.56 \\
Agree & $27.20 \%$ & 28 & 20.6 & 2.66 \\
Strongly agree & $17.50 \%$ & 18 & 20.6 & 0.33 \\
& & 103 & 103 & 12.19 \\
\hline
\end{tabular}

\section{Hypothesis B: Education of Direct Reports}

Hypothesis:

a. $\mathrm{H}_{0}$ : The responses of aviation managers regarding the need for newly hired direct reports to have a degree are equally distributed across all response choices. 
b. $\mathrm{H}_{\mathrm{a}}$ : The responses of aviation managers regarding the need for newly hired direct reports to have a degree are not equally distributed across all response choices.

A chi-square goodness of fit test was conducted to assess whether aviation managers prefer new hires to possess a degree. The results were significant, $\chi^{2}(1, N=103)=20.06, p=.00001$. The responses are generally clustered near "Neither agree nor disagree", and "Agree", and the responses for "Disagree" and "Strongly Disagree" are less than the "Agree" and "Strongly Agree". We can conclude that aviation managers do in general hold the opinion that newly hired direct reports should hold a degree. Results are presented in Table 3.

Table 3

Chi-square Calculations for Hypothesis B

\begin{tabular}{lcccc}
\hline \multicolumn{1}{c}{ Answer Options } & Response $\%$ & Observed N & $\begin{array}{c}\text { Expected } \\
\mathrm{N}\end{array}$ & $\begin{array}{c}\text { Chi } \\
\text { Squ }\end{array}$ \\
\hline Strongly disagree & 0.07 & 7 & 20.6 & 8.98 \\
Disagree & 0.15 & 15 & 20.6 & 1.52 \\
Neither agree nor & 0.29 & 30 & 20.6 & 4.29 \\
disagree & 0.3 & 31 & 20.6 & 5.25 \\
Agree Strongly & 0.19 & 20 & 20.6 & 0.02 \\
Agree & & 103 & 103 & 20.0 \\
& & & & 6 \\
\hline
\end{tabular}

\section{Hypothesis C: Degree and Level of Management}

Hypothesis:

a. $\mathrm{H}_{0}$ : There is no association between the degree level attained, and aviation managers' level of management.

b. $\mathrm{H}_{\mathrm{a}}$ : There is an association between the degree level attained, and aviation managers' level of management.

A chi-square test of independence was conducted to assess whether there was an association between the degree level attained, and aviation manager's level of management. The results of the test were not significant, $\chi^{2}(14, N=103)=9.76, p=$ .7795. There is no association between the degree level attained, and aviation managers' level of management. Results are presented in Table 4. 
Table 4

Chi-square Calculations for Hypothesis C

\begin{tabular}{lccccccccc}
\hline \multicolumn{1}{c}{ Category } & $\mathrm{a}$ & $\mathrm{b}$ & $\mathrm{c}$ & $\mathrm{d}$ & $\mathrm{e}$ & $\mathrm{f}$ & $\mathrm{g}$ & $\mathrm{h}$ & $\begin{array}{c}\text { Tota } \\
1\end{array}$ \\
\hline Lower Level & 0 & 0 & 0.57 & 0.12 & 0.32 & 1.34 & 1.83 & 0.32 & 4.5 \\
Middle Level & 0 & 0 & 0.77 & 0.56 & 0.01 & 0.06 & 0.27 & 0.01 & 1.68 \\
Top Level & 0 & 0 & 0.34 & 0.79 & 0.34 & 1.08 & 0.68 & 0.34 & 3.58 \\
& 0 & 0 & 1.68 & 1.48 & 0.67 & 2.48 & 2.78 & 0.67 & 9.76 \\
\hline
\end{tabular}

Note: The values are not counts, instead each cell is calculated as: (observedexpected $)^{2} /$ expected. The table uses the following category coding: a. Did not attend school, b. Some grade school, c. High School Diploma, d. Some college, e. Associate's Degree (2 year), f. Bachelor's Degree (4 year), g. Master's Degree (5/6 year), h. Doctoral or Professional Degree.

It is important to note that although there is no degree level association with management level and managers do not feel their education was essential to achieving their current position: (a) all respondents had at least a high school education; (b) only $2 \%$ of respondents had only a high school education; (c) $16 \%$ of respondents had some college or an associate's degree; (d) 37\% of respondents had a bachelor's degree; and (e) $45 \%$ of the respondents had an advanced degree. This indicates that the descriptive demographic data presented in Figure 1 contradicts the perceptions of the managers within that demographic.

\section{Hypothesis D: Management Important Perception}

Is there a link between the perception of degree importance and (a) management level, (b) company type, (c) salary range, (d) years in position, (e) size of company, (f) level of education, and (g) degree field of study?

\section{Hypothesis DA}

a. $\mathrm{H}_{0}$ : There is no association between degree importance perception and management level.

b. $\mathrm{H}_{\mathrm{a}}$ : There is an association between degree importance perception and management level

A chi-square test for independence was conducted to assess whether there was an association between degree importance perception and aviation manager's management level. The results of the test were not significant, $\chi^{2}(8, N=103)=$ 
$14.82, \mathrm{p}=.0627$. There is no association between the degree importance perception and aviation managers' management level. Results are displayed in Table 5.
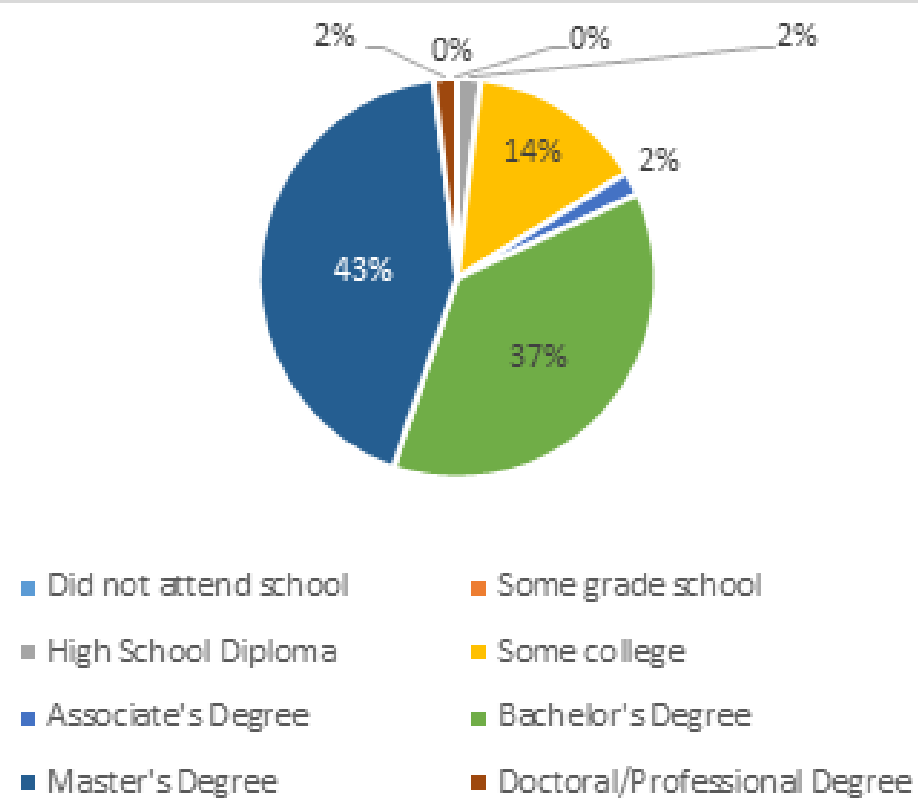

Figure 1. Pie chart displaying data on managers' education level.

Table 5

Chi-square Calculations for Hypothesis DA

\begin{tabular}{lcccccc}
\hline & \multicolumn{7}{c}{ Agreement Level } \\
Management Level & SD & D & NANDA & AG & SA & Total \\
\hline Lower Level & 1.2 & 0.07 & 0.58 & 1.22 & 0.29 & 3.36 \\
Middle Level & 0.02 & 0.41 & 0 & 1.7 & 0.71 & 2.85 \\
Top Level & 1.4 & 0.61 & 1.15 & 0.73 & 4.72 & 8.61 \\
& 2.61 & 1.09 & 1.73 & 3.66 & 5.73 & 14.8 \\
\hline
\end{tabular}

Note: The values are not counts, instead each cell is calculated as: (observedexpected $)^{2} /$ expected.

\section{Hypothesis DB}

a. $\mathrm{H}_{0}$ : There is no association between degree importance perception and company type.

b. $\mathrm{H}_{\mathrm{a}}$ : There is no association between degree importance perception and company type. 
A chi-square test for independence was conducted to assess whether there was an association between company type and degree importance perception. The results of the test were not significant, $\chi^{2}(36, N=103)=29.43, p=.7725$. There is no association between company type and degree importance perception of aviation managers. Findings are indicated in Table 6.

Table 6

Chi-square Calculations for Hypothesis DB

\begin{tabular}{|c|c|c|c|c|c|c|}
\hline \multirow[b]{2}{*}{ Company Type } & \multicolumn{5}{|c|}{ Agreement Level } & \multirow[b]{2}{*}{ Total } \\
\hline & $\mathrm{SD}$ & $\mathrm{D}$ & NANDA & $\mathrm{AG}$ & SA & \\
\hline Airline, Air Carrier & 0.02 & 0.05 & 0.83 & 0.4 & 0.33 & 1.63 \\
\hline $\begin{array}{l}\text { Airport Management, } \\
\text { Administration, or Operation }\end{array}$ & 2.77 & 1.11 & 0.17 & 0.82 & 0.2 & 5.06 \\
\hline $\begin{array}{l}\text { Aviation } \\
\text { Acquisition/Procurement }\end{array}$ & 0.69 & 0.22 & 0.65 & 2.06 & 1.58 & 5.2 \\
\hline Aviation Contractor & 0 & 0.66 & 0.33 & 1.46 & 0.01 & 2.47 \\
\hline $\begin{array}{l}\text { Aviation Support (Fuels, } \\
\text { logistics, supply, security, etc) }\end{array}$ & 0.81 & 0.81 & 0.75 & 0 & 0.68 & 3.06 \\
\hline $\begin{array}{l}\text { Design, Engineering, or } \\
\text { Manufacturing }\end{array}$ & 1 & 0.43 & 1.51 & 0 & 1.26 & 4.2 \\
\hline Education (administrators only) & 0.38 & 0.04 & 0.03 & 0.01 & 0.02 & 0.49 \\
\hline Government (Non-Military) & 3.03 & 0.44 & 0 & 1.39 & 0.13 & 4.99 \\
\hline Government (Military) & 0.08 & 0.44 & 0.01 & 0.09 & 0.35 & 0.96 \\
\hline \multirow[t]{2}{*}{ Weather Services } & 0.13 & 0.31 & 0.4 & 0.25 & 0.29 & 1.37 \\
\hline & 8.89 & 4.51 & 4.7 & 6.48 & 4.85 & 29.43 \\
\hline
\end{tabular}

Note: The values are not counts, instead each cell is calculated as: (observedexpected $)^{2} /$ expected. 


\section{Hypothesis DC}

a. $\mathrm{H}_{0}$ : There is no association between degree importance perception and salary range.

b. $\mathrm{H}_{\mathrm{a}}$ : There is an association between degree importance perception and salary range.

A chi-square test for independence was conducted to assess whether there was an association between degree importance perception and salary range. The results of the test were significant, $\chi^{2}(20, N=103)=52.29, p<.001$. Findings are presented in Table 7. A significant pattern emerges that indicates a link between salary range and degree importance perception, as depicted in Figure 2.

Table 7

Chi-square Calculations for Hypothesis DC

\begin{tabular}{lcccccc}
\hline \multicolumn{1}{c}{ Salary Range } & SD & D & NANDA & AG & SA & Total \\
\hline Less than $\$ 100 \mathrm{~K}$ & 0 & 0.02 & 0.13 & 1.09 & 0.48 & 1.73 \\
\$100K $-\$ 149 \mathrm{~K}$ & 1.15 & 0.3 & 0.3 & 0.32 & 0 & 2.08 \\
\$150K $-\$ 199 \mathrm{~K}$ & 0.78 & 0.14 & 2.33 & 1.91 & 0.04 & 5.19 \\
\$200K - $\$ 299 \mathrm{~K}$ & 0.23 & 0.1 & 0.13 & 0.82 & 0.43 & 1.71 \\
\$300K or Greater & 0.23 & 32.36 & 2.42 & 0.82 & 0.52 & 36.36 \\
I choose not to say & 0.62 & 0.58 & 0.01 & 2.17 & 1.84 & 5.22 \\
& 3.02 & 33.5 & 5.32 & 7.13 & 3.31 & 52.29 \\
\hline
\end{tabular}

Note: The values are not counts, instead each cell is calculated as: (observedexpected $)^{2} /$ expected.

\section{Hypothesis DD}

a. $\mathrm{H}_{0}$ : There is no association between degree importance perception and years in position.

b. $\mathrm{H}_{\mathrm{a}}$ : There is an association between degree importance perception and years in position

A chi-square test for independence was conducted to assess whether there was an association between years in position and degree importance perception. The results of the test were not significant, $\chi^{2}(14, N=103)=14.21, p=.4341$. There was no association between the years in position and degree importance perception of aviation managers. Results are shown in Table 8. 


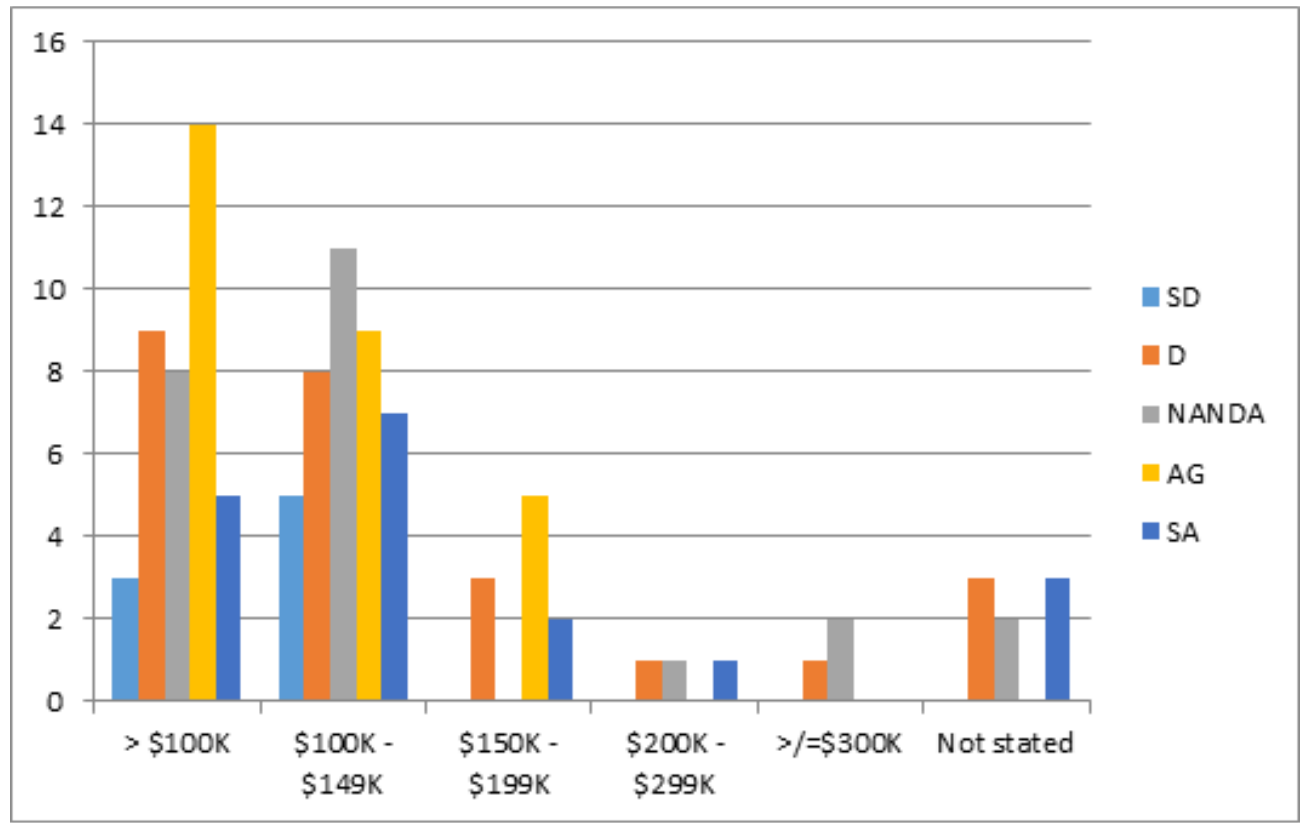

Figure 2. Level of agreement between degree importance perception and salary range.

Table 8

Chi-square Calculations for Hypothesis DD

\begin{tabular}{lcccccc}
\hline \multicolumn{1}{c}{ Years in Position } & Agreement Level \\
\hline 1 - 5 years & 0.06 & 1.61 & 0.54 & 0.01 & 0.52 & 2.74 \\
21 - 30 years & 0.06 & 1.25 & 0.3 & 0.05 & 0.89 & 2.56 \\
6 - 10 years & 0 & 0.07 & 0 & 0.02 & 6.49 & 6.59 \\
Over 30 years & 0.42 & 0.14 & 0.08 & 0.37 & 1.32 & 2.32 \\
& 0.54 & 3.07 & 0.93 & 0.44 & 9.22 & 14.21 \\
\hline
\end{tabular}

Note: The values are not counts, instead each cell is calculated as: (observedexpected $)^{2} /$ expected.

\section{Hypothesis DE}

a. $\mathrm{H}_{0}$ : There is no association between degree importance perception and size of company.

b. $\mathrm{H}_{\mathrm{a}}$ : There is an association between degree importance perception and size of company. 
A chi-square test for independence was conducted to assess whether there was an association between degree importance perception and size of company. The results of the test were not significant, $\chi^{2}(16, N=103)=15.32, p=.5013$. There is no association between the size of company and degree importance perception of aviation managers. See Table 9 for a summary of results.

Table 9

Chi-square Calculations for Hypothesis DE

\begin{tabular}{lcccccc}
\hline & \multicolumn{6}{c}{ Agreement Level } \\
\multicolumn{1}{c}{ Size of Company } & SD & D & NANDA & AG & SA & Total \\
\hline 1 to 9 & 2.42 & 0.02 & 0.39 & 0.08 & 1.57 & 4.48 \\
10 to 99 & 0.29 & 1.33 & 0 & 0.16 & 0.19 & 1.97 \\
100 to 499 & 0.81 & 2.01 & 0.22 & 0.12 & 0.01 & 3.16 \\
500 to 4,999 & 1.32 & 0 & 0.23 & 1.22 & 0 & 2.78 \\
5000 or more & 0.29 & 0.52 & 0.25 & 0.66 & 1.21 & 2.92 \\
& 5.14 & 3.87 & 1.1 & 2.24 & 2.98 & 15.32 \\
\hline
\end{tabular}

Note: The values are not counts, instead each cell is calculated as: (observedexpected $)^{2} /$ expected.

\section{Hypothesis DF}

a. $\mathrm{H}_{0}$ : There is no association between degree importance perception and level of education.

b. $\mathrm{H}_{\mathrm{a}}$ : There is an association between degree importance perception and level of education.

A chi-square test for independence was conducted to assess whether there is an association between degree importance perception and level of education. The results of the test were significant, $\chi^{2}(16, N=103)=15.32, p=.5013$. A significant pattern emerges that indicates a link between the level of education and degree importance perception. This pattern may be observed in Figure 3. Also, results are presented in Table 10.

\section{Hypothesis DG}

a. $\mathrm{H}_{0}$ : There is no association between degree importance perception and degree field of study.

b. $\mathrm{H}_{\mathrm{a}}$ : There is no association between degree importance perception and degree field of study.

A Pearson chi-square test was conducted to assess whether there was an association between degree importance perception and degree field of study. The results of the 
test were not significant, $\chi^{2}(52, N=103)=59.47, p=.2222$. There is no association between aviation managers' field of study and degree importance perception. Results are indicated in Table 11.

Table 10

Chi-square Calculations for Hypothesis DF

\begin{tabular}{lcccccc}
\hline \multicolumn{1}{c}{ Education Level } & \multicolumn{9}{c}{ Agreement Level } \\
& SD & D & NANDA & AG & SA & Total \\
\hline High School Diploma & 0.16 & 0.49 & 5.05 & 0.54 & 0.35 & 6.58 \\
Some college & 1.17 & 3.1 & 3.51 & 2.32 & 2.62 & 12.72 \\
Associate's Degree (2 year) & 2.95 & 0.49 & 0.47 & 3.9 & 0.35 & 8.15 \\
Bachelor's Degree (4 year) & 3.15 & 1.13 & 0.39 & 0.27 & 0.02 & 4.95 \\
Master's Degree (5/6 year) & 0.59 & 0.01 & 1.03 & 0.09 & 1.43 & 3.14 \\
Doctoral or Professional Degree & 0 & 0.55 & 0.61 & 0.54 & 0.35 & 2.05 \\
& 8.01 & 5.75 & 11.06 & 7.67 & 5.11 & 37.61 \\
\hline
\end{tabular}

Note: The values are not counts, instead each cell is calculated as: (observedexpected $)^{2} /$ expected.

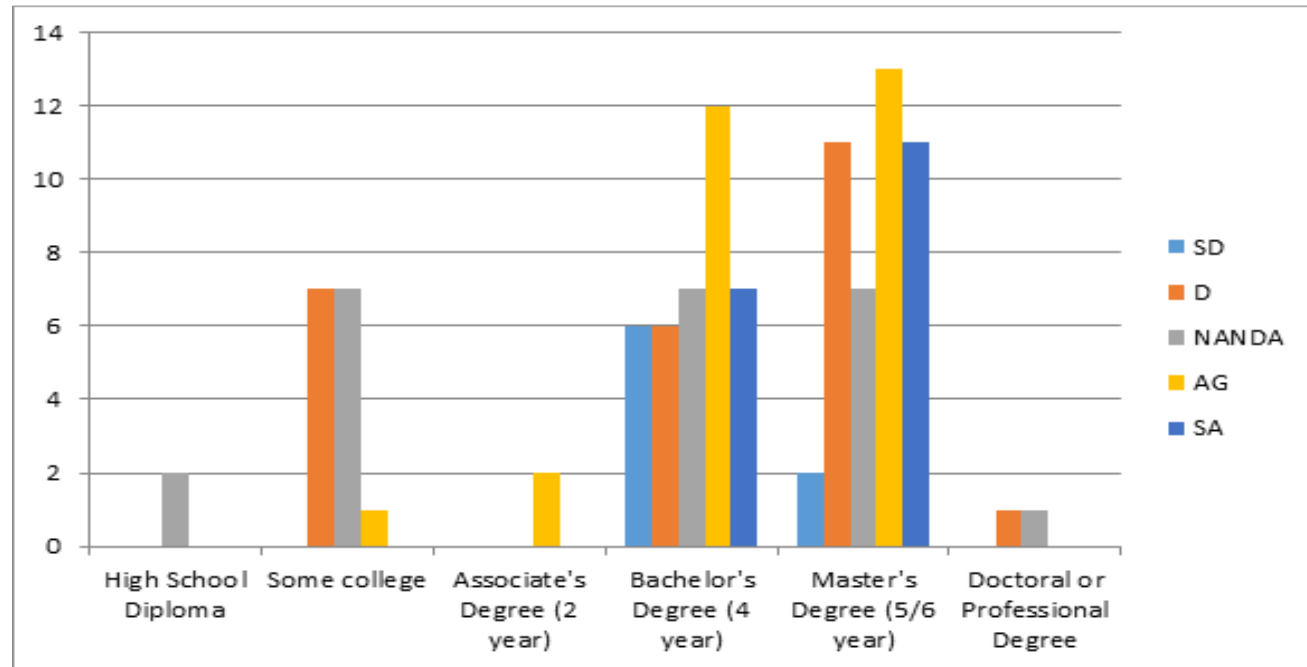

Figure 3. Level of agreement between degree importance perception and level of education. 
Table 11

Chi-square Calculations for Hypothesis DG

\begin{tabular}{lcccccc}
\hline \multicolumn{1}{c}{ Field of Study } & SD & D & NANDA & AG & SA & Total \\
\hline Aviation, Aerospace & 4.61 & 2.11 & 1.73 & 0.86 & 0 & 9.32 \\
Business, Econ, Finance, Mgmt* & 1.2 & 0.05 & 1.26 & 1.5 & 0.19 & 4.2 \\
Comm*, English, Journalism & 0.37 & 0.01 & 2.47 & 0.13 & 1.26 & 4.24 \\
Computer Science, Info Systems & 0.43 & 0 & 1.55 & 0.27 & 0.15 & 2.4 \\
Education & 0.74 & 0.63 & 1.41 & 0.26 & 0.09 & 3.13 \\
Engineering (non-aviation) & 0.02 & 0.11 & 2.56 & 0.03 & 5.64 & 8.37 \\
Fine Arts & 0.06 & 0.18 & 1.54 & 0.24 & 0.21 & 2.23 \\
Law, Criminal Justice & 0.12 & 0.36 & 0.23 & 0.58 & 0.42 & 1.72 \\
Mathematics, Other Technical & 0.25 & 0.72 & 0.47 & 1.15 & 0.84 & 3.43 \\
Medicine, Healthcare, Nursing & 0.06 & 0.18 & 1.54 & 0.24 & 0.21 & 2.23 \\
Meteorology & 0.19 & 0.54 & 4.62 & 0.71 & 0.63 & 6.69 \\
Physical Sciences & 0.31 & 0.9 & 3.89 & 0.03 & 1.05 & 6.18 \\
Social Science & 0.37 & 1.09 & 0.01 & 1.73 & 0.05 & 3.25 \\
General Studies, & $0 . J 0$ & 0.24 & 0.53 & 0.34 & 0.42 & 2.09 \\
Interdisciplinary, Other & & 7.14 & 23.82 & 8.06 & 11.16 & 59.47 \\
& 9.3 & 7.14 &
\end{tabular}

Note: The values are not counts, instead each cell is calculated as: (observedexpected $)^{2} /$ expected. *Mgmt - management; Comm - communications.

\section{Degree Discipline Analysis}

Figure 4 contains descriptive data supporting both the degree disciplines that managers possessed and the degree disciplines managers prefer new hires to have. The descriptive data demonstrates the most popular degree disciplines among the sampled managers, totaling $73 \%$ of the population, are aviation (39\%), business (29\%), and engineering (9\%). The remaining 27\% comprised of the other 14 discipline areas. The managers' most preferred degrees for new hires coincided with the foregoing, totaling $62 \%$ of the preferences, in the proportions of aviation (29\%), business (19\%), and engineering (14\%). The anomaly in the preferred category was the $12 \%$ recommendation for a computer science or information systems degree vs. the $3 \%$ of the same discipline possessed by the aviation managers. 


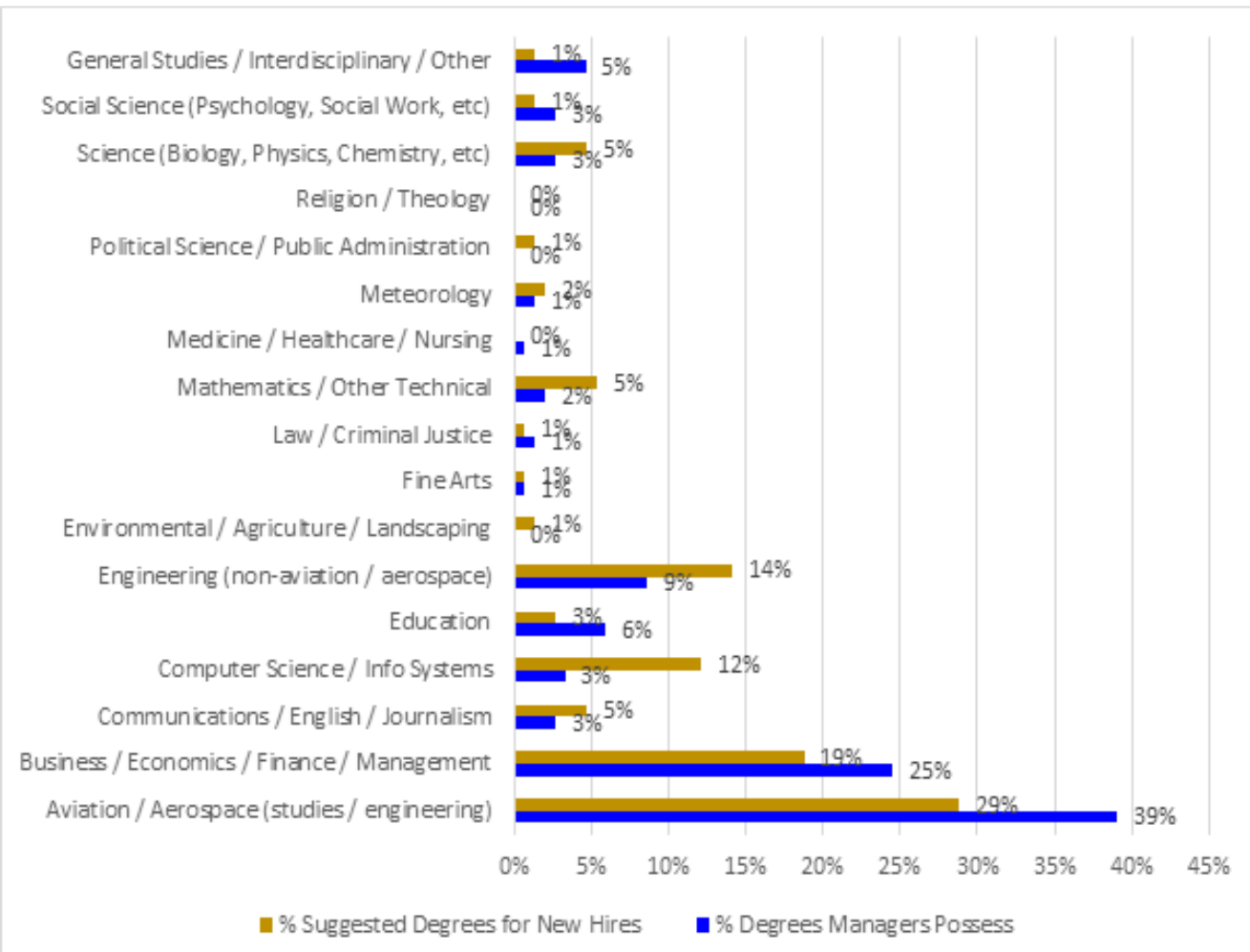

Figure 4. Degree discipline descriptive data for discussion.

The top three disciplines were divided into Group 1 and the remaining disciplines were placed into Group 2. An independent-samples $t$-test was conducted to identify any significant difference between Group 1, the most recommended degree disciplines, and Group 2, the lesser-recommended disciplines. The test was significant, $t=6.57, p<.001$, thus indicating that there is a significant preference toward the top three recommended disciplines over other degree disciplines.

\section{Discussion}

\section{Application to Professional Practice}

Although Jensen (2010) demonstrated that there is a positive return on investment for the majority of individuals who received a college education, there are no empirical studies to demonstrate the applicability of those studies specifically to the aviation industry. This study answered that call and yielded some interesting data for aviation professionals moving forward. The data indicates that, although aviation managers do not think their level of education was important to obtaining their current position, they do think that education is essential for newly 
hired employees. This finds congruence with Nadrljansku, Batinica and Zokic (2010) that found that education was extremely important among maritime managers and stressed the role of continuing and initial education. Though there were several results that did not find an association between hypotheses in the current study, there were two significant findings that have practical application for aviation managers, employees, those interested in aviation and aviation training programs. Specifically, there was a significant association between managers' salary range and degree importance perception. This could indicate that those that have degrees in the aviation industry earn significantly higher pay than those without degrees. Bastos and Monteiro (2011) found that managers wage policies are impacted by employee's education level among other factors. This finds congruence with the current research study. Furthermore the study found that aviation managers thought that the importance of education increased with the degree. This is a similar to what Pollitt (2010) noted regarding how managers with degrees translate their degree to the world of work.

There are several practical applications that those in the aviation can glean from these results. First, though the study did not find significance between managers' education level and current position, education does appear to play an important role in future hires. This could indicate that degree importance is increasing in the industry as a whole. Perhaps, previous generations of aviation managers were hired based on experience and now there is a shift in the industry where education and experience is valued. Second, the results indicate that there is an importance between salary range and degree perception below 200,000 US dollars. This may indicate that in order to advance in a company, the obtainment of a postsecondary degree is important. Aviation managers may use this data as a mentoring tool for new or high potential employees. Finally, aviation career planners, recruiters, and human resources could use the results of this study to recommend aviation, business, or engineering as a major for postsecondary education students who wish to be managers in the aviation industry. The results support the aforementioned recommendation since $62 \%$ of the suggested degree disciplines matched those categories, with the remaining $38 \%$ of suggestion divided between 14 options at significantly lower proportions. This also supports the existence and promotion aviation postsecondary education institutions, aviation degree programs, and combined aviation-business degree programs.

\section{Non-Associations}

No association was found between the following explored areas. Although the results are interesting, there is no immediately obvious reason for the lack of association. The non-associated areas might be an opportunity for future 
exploration. Our analysis concluded that there is no association between degree importance perception and management level, that is, managers of a certain level do not agree more or less that their degrees were important. There was no association between degree importance perception and company type. This means that within a given aviation industry, there was no significant relationship indicating that the managers of one company type valued education more than another. There was no association between years in position and degree importance perception of aviation managers. This means that more senior managers did not agree or disagree differently from managers with less experience.

\section{Summary and Conclusions}

In conclusion, the current research endeavor using a quantitative methodology and a sample of aviation managers, investigated the role of postsecondary education among aviation managers. There was a lack of aviationspecific research examining the relationship between aviation manager education and workforce demographic data, such as salary, management level, type of industry, and type of degree (Appelbaum \& Fewster, 2002). Therefore, the study contributed to addressing a gap in the literature, by providing current data on aviation manager's perceptions of education; furthering Carteek's (1980) seminal work. Furthermore, the study provided several recommendations for aviation managers, those currently in aviation career fields, or those interested in aviation as a future career field. The research indicates that though there is no association between several of the items tested there is a significant association between degree importance and level of education among managers that might provide utility to professional practice. Aviation career planners and human resources could use the results from the current study to recommend certain majors for those interested in a career in aviation. Aviation managers can use the results from the study as a mentoring tool for employees seeking to advance their career in the aviation industry. Also, the trends may indicate that the importance of education is increasing in the aviation industry and managers may use the results to ensure their specific organizational values are aligned with the aforementioned trends.

\section{Recommendations for Future Study}

Future studies related to aviation education could look in a variety of areas. For one, the nature of the current study was broad covering a variety of aviation related industries. Future studies could look at individual career fields in the aviation industry to see if different educational requirements are present for different fields. For example, do those in aviation maintenance have different requirements than those in aviation accounting? The current research endeavor 
reinvigorates the conversation on career planning for aviation professionals, but much work is needed to specifically outline individual career field requirements.

As previously stated, the study did not find significance between managers' education level and current position; however, education does appear to play an important role in future hires. This could indicate that degree importance is increasing in the industry as a whole. A study to explore this phenomenon might explore the gap identified via this study.

There was no association between size of company and degree importance perception. This result was unexpected given the fact that higher skilled employees require less initial training and are more appealing to smaller business, but cost more to hire (Blatter, Muehlemann, \& Schenker, 2012). We expected a relationship indicating smaller companies valued completed education more than larger companies who could better afford to train employees, but that was not the case. This could be another area for future study.

Finally, and as a complement to this study, researchers could address the qualitative gap that might provide depth and context to many of the aforementioned statistical findings. For example, with a $44 \%$ to $56 \%$ nearly even split between federal and commercial aviators, why do some choose commercial and others choose federal? A qualitative investigation might uncover why $41 \%$ of the suggested degrees for new hires to hold were aviation degrees and $27 \%$ suggested degrees were business. What specifically makes those degrees so attractive to employers? Which specific aviation major would they prefer and why? 


\section{Author Biographies}

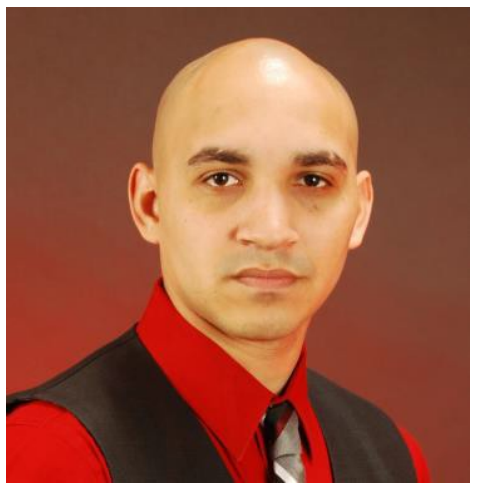

Dr. (Maj) Jason Newcomer, U.S. Air Force, is the Chief of Airfield Operations Strategic Planning at the Air Force Flight Standards Agency and an Assistant Professor of Aeronautics at Embry-Riddle Aeronautical UniversityWorldwide. As a Federal Aviation Administration certified air traffic controller and USAF certified airfield manager, he leads the branch that develops the air traffic control and landing systems Master Plan and annual Modernization Strategic Plan. He holds a Doctorate in Business Administration (DBA) specializing in Leadership (Walden University) and a Master of Aeronautical Science specializing in Space Studies and Aerospace Operations (Embry-Riddle Aeronautical University).

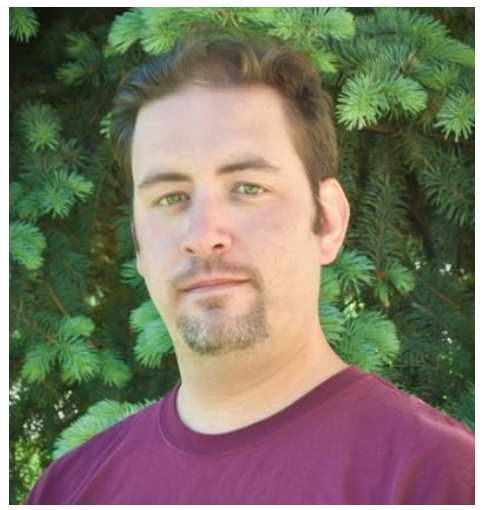

Dr. Matthew Earnhardt is an Assistant Professor with Embry-Riddle Aeronautical University-Worldwide. Prior to joining ERAU, he was the coordinator for the BUS, MAN, MAR, REE disciplines at the Community College of Aurora School of Business in addition to teaching at a variety of universities and colleges in the Denver, Colorado area. He has a diverse background in signals analysis in the military and as a defense contractor. He holds a Ph.D. in Organizational Leadership with a Global Leadership Emphasis (Regent University). He has an undergraduate degree in Psychology and a Master of Business Administration (Liberty University).

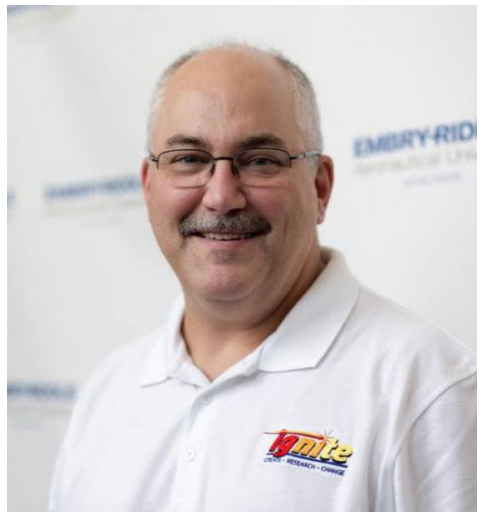

Dr. Jim Marion is an Assistant Professor with EmbryRiddle Aeronautical University-Worldwide. His experience includes multiple product launches in the US, Europe, and Asia, and significant experience with Japanese companies. He received the PMP certification in Sept, 2007. He has been teaching since 2009 for Embry-Riddle in the MS in Project Management Program, and became Chair of the MS in Engineering Management Program in 2013. Dr. Marion has a Ph.D. in Organization and Management with an Information Technology Management Specialization (Capella University). He holds an MS in Engineering (University of WisconsinPlatteville), and a MSc. and an MBA in Strategic Planning (The Edinburgh Business School of Heriot-Watt University). 


\section{References}

Appelbaum, S. H. \& Fewster, B. M. (2002). Global aviation human resource management: Contemporary recruitment and selection and diversity and equal opportunity practices. Equal Opportunities international, 21(7), 66. doi:10.1108/02610150210787226

Bastos, P. \& Monterio, N. P. (2011). Managers and wage policies. Journal of Economics \& Management strategy, 20(4), 957-984. doi:10.1111/j.15309134.2011.00310.x

Battler, M., Muehlemann, S., \& Schenker, S. (2012). The cost of hiring skilled workers. European Economic Review, 56(1), 20-35. doi:10.1016/j.euroecorev.2011.08.001

Bureau of Labor Statistics. (2014). Usual weekly earnings of wage and salary workers: Fourth quarter 2013 (Report No. USDL-14-0094). Retrieved from http://www.bls.gov/news.release/pdf/wkyeng.pdf

Cameron, A., Verhoeven, D., \& Court, D. (2010). Above the bottom line: Understanding Australian screen content producers. Media International Australia, 136, 90-102. Retrieved from http://www.uq.edu.au/mia/

Carkeet, J. (1980). Career education: Educating future aviation executives. Aviation/Space, 7(2), 23-24.

Chen, A. \& Doherty, N. (2013). The perceptions of an EMBA experience in China: An exploratory study. Journal of Management Development, 32(7), 780-795. doi:10.1108/JMD-05-2012-0069

Creswell, J. W. (2009). Research design: Qualitative, quantitative, and mixed methods approaches ( $3^{\text {rd }}$ Ed.). Thousand Oaks, CA: Sage

Daniels, V.S. (2011). Assessing the value of certification preparation programs in higher education. American Journal of Business Education, 4(6), 1-10. Retrieved from http://journals.cluteonline.com/index.php/AJBE 
Eaton, J. (2001). Globalization and human resource in the airline industry $\left(2^{\text {nd }}\right.$ ed.). Aldershot, UK: Ashgate Publishing Ltd.

Haase, C. (2009). Global trends in salary, status, responsibilities and career progression: What does the future hold for the business continuity professional? Journal of Business Continuity \& Management, 3(4), 291301. Retrieved from http://www.henrystewartpublications.com/jbcep/v3

George, K. W. (2012). That used to be us: Through the eyes of the aviation industry. Collegiate Aviation Review, 30(1), 62-76. Retrieved from http://www.imis100us1.com/uaa/UAAMain/Publications/CAR_Files/Colle giate_Aviation_Review.aspx

Jensen, R. (2010). The (perceived) returns to education and the demand for schooling. The Quarterly Journal of Economics, 125(2), 515-548. doi:http://dx.doi.org/10.1162/qjec.2010.125.2.515

Katkin, R., Tien, S., Topiwala, T., Conroy, J., Guensch, C. A., \& You, H. (2013). Developing early alerting mechanism to support robust terminal radar approach control operations. Transportation Research Record, 2336, 1826. doi:10.3141/2336-03

Koskela, I. \& Palukka, H. (2011). Trainer interventions as instructional strategies in air traffic control training. Journal of Workplace Learning, 23(5), 293314. doi:10.1108/13665621111141902

LaPoint, J. L. (2012). The effects of aviation error management training on perioperative safety attitudes. International Journal of Business and Social Science, 3(2), 77-90. Retrieved from http://www.ijbssnet.com

McCain, B. M. (2010). The relationship between perceived leadership practices and organizational culture within the aerospace industry (Doctoral dissertation). Retrieved from ProQuest Dissertations and Thesis database. (UMI No. 3434017)

McKee, A. \& Silver, J. (2012). The relationship between entertainment producers and higher education providers. Media International Australia, 145, 18. Retrieved from http://www.uq.edu.au/mia/ 
Moorien, N. P., Warren, J. P., Morris, D., \& Enoch, M.P. (2013). Mapping expert perspectives of the aviation sector. International Journal of Environmental Technology and Management, 16(3), 179-202. doi:10.1504/IJETM.2013.053631

Nadrlijanski, M., Batinica, V \& Zokic, M. (2010). Education of Mmaritime managers. MIPRO, Proceedings of the $33^{\text {rd }}$ International Convention.

NASA. (2010). Work Breakdown Structure (WBS) Handbook. Washington, DC: Author.

Newton, W. P. (2004). The origins and early development of civil aviation in Montgomery, 1910-1946. Alabama Review, 57(1), 6-25. Retrieved from http://www.uwa.edu/alabamareview/

Noor, A. K., Venneri, S. L. \& Creedon, J.F. (2003). The first hundred are the hardest. Mechanical Engineering, 30-34.

Paraschivescu, V., \& Radu, C. E. (2011). Higher education, a resource for sustainability. Economy Transdisciplinarity Cognition, 14(1), 115-120. Retrieved from www.ugb.ro/etc

Pollitt, D. (2010). Norbert Dentressangle delivers managers of tomorrow: Foundation-degree students impress course leader. Human Resource Management International, 18(1), 20-22. doi:10.1108/09670731011016152

Pourdehnad, J. \& Smith, P.A.C. (2012). Sustainability, organizational learning, and lessons learned from aviation. The Learning Organization, 19(1), 7786. doi:10.1108/09696471211190374

Quinlan, M., Hampson, I., \& Gregson, S. (2013). Outsourcing and offshoring aircraft maintenance in the US: Implications for safety. Safety Science, 57, 283-292. doi:10.1016/j.ssci.2013.02.011

Rango, A., Laliberte, A. S. (2010). Impact of flight regulations on effective use of unmanned aircraft systems for natural resources applications. Journal of Applied Remote Sensing, 4(1), 1-12. doi:10.1117/1.3474649 
Robinson, K. J. (2013). The high cost of education and federalism. Wake Forest Law Review, 48, 287-331. Retrieved from http://wakeforestlawreview.com/

Romano, K. W. (2003). The influence of organizational culture, leadership, and structure on operational effectiveness in the aerospace industry (Doctoral dissertation). Retrieved from ProQuest Dissertations and Thesis database. (UMI No. 3129926)

Sampson, Jr., E., \& St. James II., W. D. (2012). Mentorship interactions in the aviation or aerospace industries. Academy of Strategic Management Journal, 11(2), 35-49. Retrieved from http://www.alliedacademies.org/Public/Journals/JournalDetails.aspx?jid=1 3

Schmader, K. E. (2011, January). Essentials of pilot study design. Presented at the Duke University Pilot Studies Workshop, Durham, NC.

Small, M. W. \& Minkes, L. (2010). On the nature of learning communities: A study of four Organisations [SIC]. The Journal of Management Development, 29(9), 783-794. doi:10.1108/02621711011072496

Swartz, S. M. (2008). Managerial perceptions of project stability. Project Management Journal, 39(4), 17-32. doi:10.1002/pmj.20078

Tjorhom, B. B. (2010). Risk governance within aviation. Risk Management, 12(4), 256-284. doi:10.1057/rm.2010.5

Tomczyk, A. (2010). The flying laboratory for aeronautics students' education. Aircraft Engineering and Aerospace Technology, 82(5), 320-330. doi: 10.1108/00022661011092965

Van Eckert, S., Gaidys, U. \& Martin, C. R. (2012). Self-esteem among German nurses: Does academic education make a difference? Journal of Psychiatric and Mental Health Nursing, 19(10), 903-910. doi:10.1111/j.1365-2850.2011.01862.x

Van Praag, M., van Witteloostuijn, \& van der Sluis. (2013). The higher returns to former education for entrepreneurs versus employees. Small Business Economics, 40(2), 375-396. doi:10.1007/s11187-012-9443-y 
Walsemann, K. M., Bell, B. A., \& Hummer, R. A. (2012). Effects of timing and level of degree attained on depressive symptoms and self-rated health at midlife. American Journal of Public Health, 102(3), 557-563. doi:10.2105/AJPH.2011.300216

Wicks, F. (2003). Trial by flyer. Mechanical Engineering, 4-10.

Wofford, M. G., Ellinger, A. D., \& Watkins, K. E. (2013). Learning on the fly: exploring the informal learning process of aviation instructors. Journal of Workplace Learning, 25(2), 79-97. doi: 10.1108/13665621311299771

Yi-Hsin, L. (2012). Knowledge brokering for transference to the pilot's safety behavior. Management Decision, 50(7), 1326-1338. doi: $10.1108 / 00251741211247030$

Yin, R. K. (2009). Case study research: Design and methods ( $4^{\text {th }}$ ed.). Thousand Oaks, CA: Sage.

Zinko, R., Gentry, W. A., Hall, A. \& Grant, G. L. (2012). Reputational change among managers. Journal of Managerial Issues, 24(1), 9-26. Retrieved from http://www.pittstate.edu/department/economics/journal-ofmanagerial-issues/ 